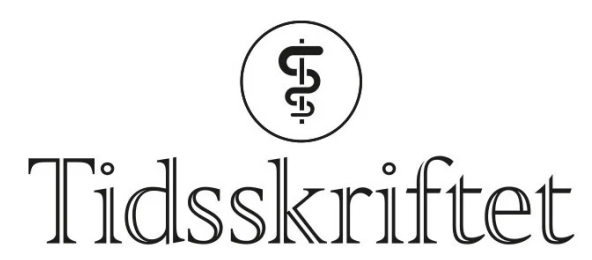

DEN NORSKE LEGEFORENING

\title{
Å skyte spurv med kanoner
}

PERSONLIGE OPPLEVELSER

Min kone Ellen Tvergrov Grytting skrev en artikkel om å bli hengt ut i pressen. Artikkelen sto på trykk i Tidsskriftet i 1994. Hun ville den gang være anonym, men jeg tror ikke hun hadde hatt noe imot å bruke navnet sitt i dag. Hun døde i mars 2011.

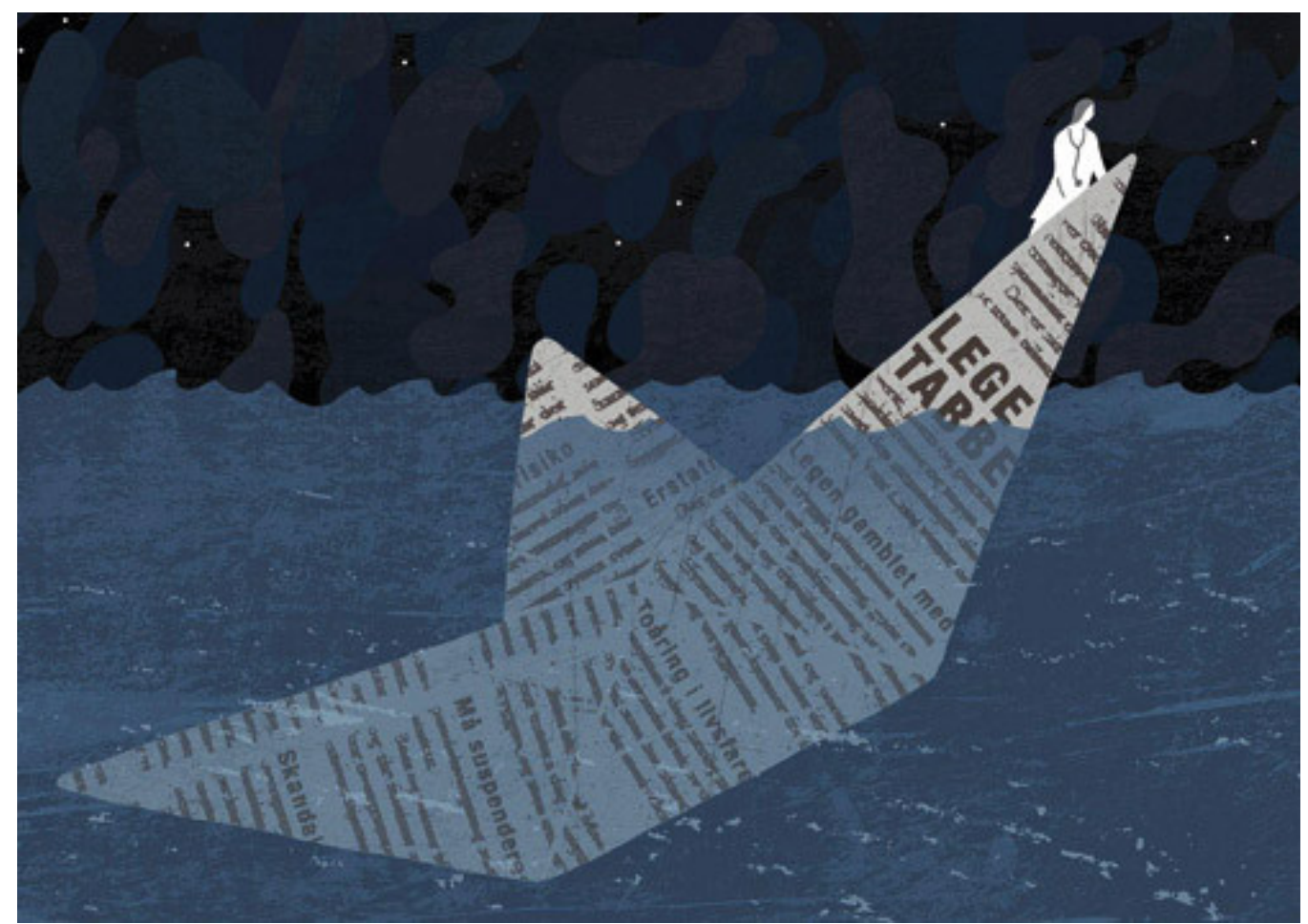

Illustrasjon Svein Størksen

Artikkelen fra 1994 (11) ble trykt opp igjen i forbindelse med 125-årsjubileet til Legeforeningen i 2011 (므). Redaksjonen fors økte i forbindelse med bokprosjektet å få kontakt med flere anonyme forfattere, også Ellen, men lyktes ikke. Jeg er i etterkant blitt gjort oppmerksom på dette, og ble oppfordret av redaksjonen om å skrive noen refleksjoner.

Etter artikkelen 
I artikkelen skrev hun om å bli hengt ut i avisen som «den farlige og udugelige lege». Hendelsen gjorde sterkt inntrykk på henne og var nok medvirkende til at hun på denne tiden begynte å gå lei av hverdagsmedisinen. Hun sier selv i artikkelen at hun var på vei inn i en tilstand av utbrenthet. Hun kom opp i en situasjon som kunne skje hvem som helst av oss, men som vi takler forskjellig. Den beste hjelpen Ellen fikk etter avisoppslaget, tror jeg var all støtte og positiv tilbakemelding som hun fikk ved å snakke om hendelsen i forskjellige fora. Viktig for henne var også at hun i årene som fulgte tok noen sommervikariater ved Longyearbyen sykehus, noe som ga et avbrekk i hverdagen, og var en stor naturopplevelse som hun levde lenge på.

Ellen var faglig solid og fulgte godt opp sine pasienter. Hun var psykisk robust. Det at hun ble beskyldt for å gjøre en så dårlig jobb at anklageren mente hun burde suspenderes fra jobben var likevel i overkant av hva hun kunne tåle. Det var en styrke at hun faglig sett hadde handlet riktig etter egne og kollegers mening. Det var kommunikasjonen mellom henne og barnets far som hadde skapt mistillit og utrygghet hos faren, og det tok hun selvkritikk på. Hun hadde også forståelse for at faren hadde behov for å finne en syndebukk for barnets alvorlige tilstand. Det var oppslaget i lokalavisen med fullt navn som var mest vanskelig å forholde seg til. Når man føler seg urettmessig behandlet, er første tanke å forsvare seg. Etter nøye vurdering valgte hun likevel å bite det i seg, i håp om at saken ble fortere glemt på den måten enn om hun skulle forfølge saken i pressen.

\section{Til slutt}

Det gikk noen år før hun selv fikk denne hendelsen på avstand. Men helt glemt ble den nok aldri. Hun avsluttet artikkelen med at hun klarte denne omgangen, men stilte spørsmål ved om hun kunne klare én til. Heldigvis slapp hun det. Lysten til å fortsette som allmennlege kom tilbake og varte livet ut. Hun fulgte godt med i hvordan det gikk med pasientene sine lenge etter at hun selv var blitt alvorlig syk.

Hendelsen viser med all tydelighet hvor viktig kommunikasjonen mellom lege og pasient er. Grensen mellom å skape tillit og trygghet på den ene siden, og det å virke arrogant og bagatelliserende på den andre siden, er lett å tråkke over i samtaler med mennesker man ikke kjenner. Derfor er det på legevakten de fleste slike hendelser skjer. Når lege og pasient kjenner hverandre, er risikoen for misforståelser mindre.

\section{LITTERATUR}

1. Å skyte spurv med kanoner. Tidsskr Nor Lægeforen 1994; 114:354-5.

2. Å skyte spurv med kanoner. I: Hem E, Haug C, red. Livet som lege. Oslo: Den norske legeforening, 2011:19-21.

Publisert: 27. mars 2012. Tidsskr Nor Legeforen. DOI: 10.4045/tidsskr.12.0237

Mottatt 1.2.2012 og godkjent 9.2.2012. Medisinsk redaktør Erlend Hem.

(C) Tidsskrift for Den norske legeforening 2023. Lastet ned fra tidsskriftet.no 26. april 2023. 